\title{
Romantik İlişkilerde Sosyal Medya Kıskançlı̆̆ı Ölçeği (RİSMKÖ): Geçerlik ve Güvenirlik Çalışması
}

\author{
DOI: $10.26466 /$ opus.890331
}

\author{
Yunus Emre Aydın * - Nezaket Bilge Uzun** \\ * Uzm. Psik. Danışman, Şahinbey Rehberlik ve Araştırma Merkezi, Şahinbey/Gaziantep/Türkiye \\ E-Posta: pd.yemreaydin@gmail.com $\quad$ ORCID: 0000-0002-6227-4926 \\ ** Doç.Dr., Mersin Üniversitesi, Eğitim Fakültesi, Yenişehir/Mersin/Türkiye \\ E- Posta: n.bilgeuzun@gmail.com ORCID: $\underline{0000-0003-2293-4536}$
} Öz

Bu çalı̧manın amacl; herhangi bir romantik ilişki yaşamış ve yaşamakta olan bireylerin romantik ilişkilerde sosyal medya kıskançlğ̆ın ölçen güvenilir ve geçerli bir ölçek aracı geliştirmektir. Bu amaç doğrultusunda aday ölçek formu oluşturma sürecinde; "niteliksel adımlar"dan (odak grup görüşmeleri, kompozisyon yazdırma, alan yazm ölçek taraması) ve "niceliksel adımlardan" (geçerlik ve güvenirlik analizleri) yararlanılmıştır. 57 maddelik formdan uzman değerlendirmeleri sonrası kapsam geçerlik oran .80'in altında olan maddeler çıkartılmış ve 53 madde kalmıştır. Oluşturulan 53 maddelik ve beşli likert tipindeki denemelik ölçek formu herhangi bir romantik ilişki yaşayan veya yaşamış olan 18-56 yaş arasındaki 417 bireye uygulanmıştır. Açımlayıcı Faktör Analizi (AFA)'nın temel sayıltıları sinanmış olup; AFA sonucunda "Kısıtlayıcı ve Kontrolcü Tutum", "Şüpheci ve Gözetleyici Tutum" ve "Sosyal Medya Alantna Saygı ve Güven" olmak üzere 3 boyutlu toplam 21 maddeden oluşan yapı elde edilmiştir. RISMKÖ psikolojik yapı geçerliğini incelemek amacılla; AFA sonrasında oluşan 21 maddelik nihai form ile 332 birey ile yeniden veri toplanmış; DFA öncesi yine sayıltılar test edilmiş ve doğrulayıc faktör analizi (DFA) yapılmıştır. DFA sonucunda; alt boyutlara ait standardize yük değerleri, değişkenlere ilişkin kestirilen hata varyansları, tüm maddelerin T değerleri ve model uyum iyiliği değerleri incelendiğinde ölçeğinin 21 maddeden oluşan 3 faktörlü yapısının bir model olarak doğrulandığ tespit edilmiştir. DFA sonrasında ölçeğin yakmsak geçerlik, traksak geçerlik ve birleştirici güvenirlik değerleri incelendiğinde genel anlamda ölçütlere uygun değerler olduğu görülmektedir. Son olarak; Cronbach alfa iç tutarlk katsayısl; ölçeğin tamamı için .922, "Kısıtlayıcı ve Kontrolcü Tutum" için .878, "Şüpheci ve Gözetleyici Tutum" için .881, "Sosyal Medya Alanına Saygı ve Güven" için .878 olarak hesaplanmıştır. Tüm bu bulgular incelendiğinde; romantik ilişkilerde sosyal medya kıskançlğııı ölçmede güvenilir ve geçerli bir ölçek olduğu sonucuna varılmıştır.

Anahtar Kelimeler: Romantik Ilişki, Sosyal Medya, Kıskançlık, Ölçek. 


\title{
Scale of Social Media Jealousy in Romantic Relationships (SSMJRR): A Study of Reliability and Validity
}

\begin{abstract}
The aim of this study is to develop a reliable and valid scale tool that measures social media jealousy in romantic relationships of individuals who have had and are currently living in a romantic relationship. For this purpose, in the process of creating a candidate scale form; "qualitative steps" (focus group interviews, essay printing, literature scale scanning) and "quantitative steps" (validity and reliability analysis) were used. Items with content validity rate below .80 after expert evaluations were removed from the 57-item form and 53 items remained. The 53-item and five-point likert-type trial scale form was applied to 417 individuals between the ages of 18-56 who had or had a romantic relationship. The basic assumptions of Explanatory Factor Analysis (EFA) have been tested; As a result of EFA, a structure consisting of a total of 21 3-dimensional items, namely "Restrictive and Controlling Attitude", "Skeptical and Observant Attitude", and "Respect and Trust in the Field of Social Media", was obtained. In order to examine the psychological construct validity of Social Media Jealousy in Romantic Relationships Scale; With the final form consisting of 21 items formed after EFA, data were collected again with 332 individuals; Before CFA, assumptions were tested and confirmatory factor analysis (CFA) was performed. As a result of DFA; When the standardized load values of the sub-dimensions, the estimated error variances for the variables, the $T$ values of all items and the goodness of fit of the model were examined, it was found that the 3-factor structure of the scale consisting of 21 items was confirmed as a model. When the convergent validity, divergent validity and combining reliability values of the scale after CFA are examined, it is seen that the values are suitable for the criteria in general. Finally; Cronbach alpha internal consistency coefficient; 922 for the whole scale, .878 for "Restrictive and Controlling Attitude", .881 for "Skeptical and Observant Attitude", and .878 for "Respect and Trust in Social Media". When all these findings are examined; It was concluded that it is a reliable and valid scale for measuring social media jealousy in romantic relationships.
\end{abstract}

Key Words: Romantic Relationship, Social Media, Jealousy, Scale. 


\section{Giriş}

Kıskançlık; insanoğlunun doğumdan ölüme kadar giden yaşam yolculuğunda yaşayabildiği veya tanık olduğu duygusal, davranışsal, düşünsel boyutları olan bir kavramdır. Ayrıca kıskançlığın birçok türü olmakla birlikte geçmişten günümüze kıskançlığı açıklayan birçok farklı veya benzer tanımlamalar da yapılmıştır. Kıskançlık; bir kimse bir üstünlük gösterdiğinde ya da sevilen birisinin, başkası ile ilgilendiği kanaatine varıldığında takınılan olumsuz tutum, günücülük, hasetçilik, hasetlik, hasutluk olarak tanımlanmaktadır (TDK, 2020). Pines'e göre (2003) kıskançlık; değerli bir ilişkinin yitirilmesi veya bozulmasına yol açabilecek bir tehdit durumunda verilen karmaşık bir tepki olarak tanımlanmıştır. Topkara'ya göre (2011) kıskançlık; karşımızdakini kaybetme korkusuyla ortaya çıkan ve onu başka birisiyle paylaşmak zorunda kalmayı hissetmeye karşı gösterdiğimiz, iç dünyamızda oluşan duygusal bir tepkidir.

Freud'a göre kıskançlık; üzüntü, kaygı gibi "normal" olarak değerlendirebilecek duygu durumlardan biridir. Kiskançlık doğuştan gelen ve evrensel olan bir duygu olmakla birlikte 6 aylık bebeklerde dahi görülebilmektedir. Örneğin bebeklerin onların genellikle bakımlarını üstlenen, sevgiyi veren annelerini kıskandığı görülür. İnsan hayatının ilk yıllarındaki anneye duyulan rekabete ilişkin aşk ve odipal çatışma ile başlamaktadır. Bir süre sonra kız çocukları babaya erkek çocuklar ise annesine âşıktır ve kız çocuklar babasını annesinden, erkek çocuklar ise annesini babasından kıskanır. Aslında çocuklukta yaşadıkları bu kıskançlıklar yetişkinlik dönemlerindeki kıskançlıklarında etkili rol oynar. Freud'a göre yetişkinlik döneminde yaşanılan kıskançlığın temeli, çocuklukta ödipal evredeki yaşantılardır. Freud'a göre bireyin kıskançlık yaşamadığını inkâr etmesi aslında bir savunma mekanizmasıdır. Freud normal olarak değerlendirdiği kıskançlığı ise tümüyle akılcı, gerçek nedenlere ve şartların gerekleri doğrultusunda gerçekleştiği anlamına da gelmediğini ifade etmiştir (Demirtaş, 2004; Deutsch, 2006; Freud, 1998). Freud'un kıskançlı̆̆ın kökenlerinin; âşık olunan kişiyi kaybetme korkusunun sebep olduğu "üzüntü", insanın elde etmek istediği her şeyi elde edemeyeceğine ilişkin "acı farkındalık", bireyin rakiplerinin kendisinden daha iyi olmasıyla ortaya çıkan "haset duyguları" ve kişinin kaybından kendisini mesul tutmasına ilişkin görülen "öz-eleştiri" den oluştuğunu ifade etmiş- 
tir (Pines, 2003). Mead (1977) kıskançlığın bireyin kendine saygısına yönelik tehditler nedeniyle ortaya çıktığını ifade etmiştir. Kıskaçlığ mal" olarak değerlendirenlere katılmamaktadır. Onu "talihsiz" bir duygu olarak nitelendirmiştir. Ayrıca kadınların daha güvensiz olmaları nedeniyle erkeklere göre daha kıskanç olabileceklerini ifade etmiş; bu güvensizliğin nedeni olarak da toplumdaki göreli zayıflıklarından kaynaklandığını düşünmektedir (Mathes, 1992).

Kıskançlık ile ilgili alan yazın incelendiğinde; kıskançlığın insanlar arasında arkadaş kıskançlığı, kardeş kıskançlı̆̆ 1 ve romantik kıskançlığ 1 olmak üzere genelde 3 tür olarak yaşandığı belirtilmiştir. Arkadaş kıskançlığı; okul, iş ve çevre ortamında çekirdek aile dişındaki insanlarla kurulan iletişimde kendini göstermektedir (Akan, 2019). Diğer bir kıskançlık türü olan kardeş kıskançlığı; kardeşler arasında ebeveyn sevgisi ve ilgisinin paylaşılması noktasında oluşan bir yarışma veya anlam verilemeyen bir duygu karmaşası olarak tanımlanmıştır (Yavuz, 2007; Akoğlu ve Şipal, 2012). Romantik kıskançlık ise duygusal yakınlığa dayalı genellikle karşı cinsle yaşanan romantik ilişkilerde kendini gösteren olumsuz karmaşık duygulardır (Tortamış, 2014). Bu çalışmada da özellikle romantik kıskançlık ele alınmıştır.

Kıskançlık terimiyle birlikte ilk akla gelen kıskançlık türü romantik kıskançlıktır. Romantik kıskançlık ise duygusal yakınlığa dayalı olarak genellikle karşı cinsle yaşanan romantik ilişkilerde (partnerler arasında) bir ilişkinin bitmesine ya da yapısının zarar görmesine neden olabilecek gerçek ya da algılanan bir tehdit karşısında verilen olumsuz karmaşık tepki olarak tanımlanmaktadır (Pines, 1998; Tortamış, 2014). Diğer bir tanımlamaya göre ise romantik kıskançlık; kişinin partneri ile hayali ya da gerçek bir rakip arasındaki gerçek ya da olası bir ilişki sebebiyle alg1lanan, birlikteliğin varlığına ya da değerine veya kişinin kendisine sayg1sına yönelik birtakım tehditlere eşlik eden düşünce, duygu ve davranışlar bütünü olarak tanımlanmıştır (White,1981). Guerrero, Spitsberg ve Yoshimura (2004) göre romantik kıskançlık, kişinin birlikteliğine veya ilişkisine yönelik bir tehdit algıladığında göstermiş olduğu davranışsal, bilişsel ve duygusal tepki/tepkiler olarak tanımlanmaktadır.

Transaksiyonel Yaklaşım'a göre kıskançlık birçok türde kendini göstermekle birlikte diğer kıskançlık türlerine göre daha güçlü, daha stres verici, daha karmaşık ve belirgin olarak kendini gösteren türü "romantik 
kıskançlık" tır (Demirtaş,2004). Bu yaklaşıma göre üçüncü biri ile kurulan ilişki bireyin ilişkisel ödüllerini azaltma veya kaybetme riskini gündeme getirerek ortaya çıkar. "Partnerini kaybetme korkusu" kıskançlığın nedenlerinden biri olabilir; fakat tek neden de bu değildir. Zaman kaybı, ilişki kaybı, statü kaybı, özel alana müdahale, eşe yönelik olumsuz duygular gibi birçok sebep bu durumu ortaya çıkarabilir (Bringle, 1995).

Dijitalleşen dünya ile insanlar; gerçek dünyada olduğu gibi sanal dünyada da kendilerini göstermektedirler. Böylece insanların gerçek kimliklerini yanısıra sanal kimlikleri de oluşmaktadır. İnsanlar bu sanal kimliklerini sosyal ağlar ve "sosyal medya" araciliyla diğer insanlarla paylaşmaktadırlar (Dursun ve Barut, 2016). Sayımer (2008, s.123) sosyal medya kavramını; kullanıcılara enformasyon, düşünce, ilgi ve bilgi paylaşım imkânı tanıyarak karşılıklı etkileşim yaratan çevrimiçi araçlar ve web siteleri için ortak kullanılan bir terim olarak tanımlamıştır. Diğer bir tanımlamaya göre ise sosyal medya; insanların kişisel profil oluşturdukları, diğer sosyal medya kullanıcıları ile karşılıklı iletişim ve etkileşim içinde bulundukları, ortak ilgilere sahip kişilerle paylaşımlarını artırdıkları, iletişim kurmak istedikleri arkadaş listesini oluşturdukları web tabanlı uygulamalar olarak açıklamaktadır. (Boyd, 2003; Vural ve Bat, 2010). Sosyal medyanın; büyük topluluklara ulaşım kolaylığı sağlaması ve hızlıca ulaşılabilmesi, kullanımının kolay olması, güncelleme yapılabilmesi, ayrıca çok düşük maliyette veya ücretsiz olması gibi özelliklere sahip olması (Korkmaz, 2012) insanların sosyal medya kullanımına daha da çok cezbetmektedir.

Sosyal medyanın günlük yaşamın bir parçası olmasıyla birlikte sosyal medyadaki ilişkiler, yüz yüze iletişim kadar önemli hale geldiği görülmüştür. Daha önemlisi, romantik ilişkiler açısından bakıldığında çiftlerin-partnerlerin ilişkilerini yaşarken birbirlerinin sosyal medya şifrelerini öğrenme isteği, arkadaş listelerini kontrol etme, nerelere gittiği hakkında bilgi sahibi olma, kimlerin fotoğrafını beğenme gibi davranış kalıpları geliştirdikleri görülmeye başlanmıştır. Aslında çiftler arasında yaşanan bu durumlar; sosyal medya kullanımın çiftlerin ilişkilerinde ne kadar etkili olduğunu ortaya koymaktadır. Çiftler arasındaki bu durum ise kıskançlık duygusu ile ilgili olduğu söylenebilir (Alikılıç, Alikılıç ve Özer, 2019; Tokunaga, 2011). 
Günümüzdeki en çok kullanılan sosyal medya uygulamalarından olan Facebook, Instagram, Twitter vb. uygulamalar; geçmişteki ilişkilere olanak sağlaması, alternatif ilişkilerin kurulması için uygun bir ortam sunması gibi sebeplerle günümüzde kıskançlık tetikleyicisi ve partner şiddeti nedeni olarak değerlendirilmektedir. Romantik ilişkilerde partnerler; sahte bir hesap oluşturarak partnerini gözetleme, karşı cinsten birini arkadaş olarak ekleme, partnerinin profilini uzun uzun ve daha sık inceleme vb. güvensiz, kontrolcü davranışlar sergiledikleri görülmektedir (Gençer, Karadere, Okumuş ve Hocaoğlu, 2018).

Romantik ilişkilerde sosyal medya kıskançlığı; teknoloji, internet ve ardından sosyal medyanın yaygın kullanımı ile ortaya çıkan ve partnerler arasındaki ilişkinin zarar görmesine sebep olabilecek olumsuz karmaşık tepki olarak adlandırılabilir. Sosyal medyanın kullanım avantajları da düşünüldüğünde (kolay kullanım, hızlıca ulaşılabilirlik, düşük maliyet veya ücretsiz olması vs.) ve sosyal medya güncellenen uygulamalarla birlikte partnerler arasında gitgide daha yaygınlaşmakta ve daha farklı rollere bürünmektedir. Son zamanlarda romantik ilişkilerde sosyal medya kıskançlığı yaşayan partnerlerin; sosyal medya şifrelerini öğrenme isteği, arkadaş listelerini kontrol etme, nerelere gittiği hakkında bilgi sahibi olma gibi davranışlarının yanısıra son çevrimiçi/aktiflik saatini kontrol etme, partnerinden bazı fotoğrafları silmesini isteme, partnerinin fotoğrafını beğendiği hesapları tek tek inceleme, farklı sahte bir profil oluşturma gibi gitgide daha karmaşıklaşan davranış kalıpları geliştirdikleri görülmektedir.

Alan yazın incelendiğinde; romantik ilişkilerde sosyal medya kıskançlığına yönelik ülkemizde ölçek geliştirme çalışması olmadığı görülmektedir. Muise, Christofides ve Desmarais (2009) tarafından orijinal adıyla "Facebook Jealousy Questionnaire" geliştirişmiş ve bu ölçeğin Türk kültürüne uyarlama çalışması Madran (2016) tarafından yapılmıştır. Madran (2016) Facebook Kıskançlık Ölçeği'nin uyarlamasını gerçekleştirmesinin yanısıra bu tür uyarlama çalışmalarının, yeni araştırmalar yapma olanağı sağlamanın yanında, kültüre özgü yeni ölçekler geliştirmek için de bir basamak işlevi görebilmekte olduğunu ifade etmiştir. Bu noktada; bu çalışmanın da amacı romantik ilişkilerde sosyal medya kıskançlığını ölçmeye yönelik geçerliği ve güvenirliği test edilmiş bir ölçme aracı geliştirmektir. 


\section{Yöntem}

$\mathrm{Bu}$ araştırma; herhangi bir romantik ilişki yaşamış veya yaşamakta olan yetişkin bireylerin romantik ilişkilerinde sosyal medya kıskançlıklarını ölçmeye yönelik bir ölçek geliştirilmesi amaçlanan temel araştırma niteliğindedir.

\section{Çalışma Grubu}

Bu araştırmanın açımlayıcı faktör analizi için çalışma grubu; herhangi bir romantik ilişki yaşamış ve yaşamakta olan 18-56 yaş arasındaki 417 bireyden (veriler 2021 yılı Ocak ayında toplanarak) oluşmaktadır. Çalışma grubunu araştırmaya gönüllü katılan bireyler oluşturmuştur. Katılımc1ların 336'sı kadın (\%80.16) ve 81'i erkek (\%19.4) bireylerden; 134'ü evli (\%32.1), 31'i nişanlı/sözlü (\%7.4), 155'i flört/sevgili (\%37.2) ve 97'si daha önceden bir romantik ilişki yaşamış olup şu an ayrılma, boşanma durumundaki bireylerden (\%23.3) oluşmaktadır.

Açımlayıcı faktör analizi sonrasında oluşan nihai form ile ölçeğin yapı geçerliğini incelemek amacıyla (doğrulayıcı faktör analizi) yeniden veri toplama yoluna gidilmiş (2021 Şubat ayında) ve herhangi bir romantik ilişki yaşamış veya yaşamakta olan 332 yetişkin bireye ulaşılmıştır.

\section{Aday Ölçek Formunun Oluşturulma Süreci}

1.Adım (Odak Grup Görüşmeleri): Madde havuzu oluşturma sürecinde; 8 psikolojik danışman ile iş yoğunluğunun en az olduğu gün ve saatte odak grup görüşmesi gerçekleştirilmiştir. Odak grup görüşmesine kat1lacak kişileri oluşturmak amaciyla çalışma grubu oluşturulmuş; bu grup oluşturulurken nitel araştırma örneklem yöntemlerinden elverişli örneklem kullanılmıştır.

2.Adım (Kompozisyon Yazdırma): Yine, veri toplamak amaciyla Mersin Üniversitesi Eğitim Fakültesi'nde Pedagojik Formasyon eğitimi alan 69 bireye konu ile ilgili görüşlerini yazılı olarak ifade etmelerine olanak tanıyan açık uçlu sorulardan oluşan bir kompozisyon yazdırılmıştır. 
3.Adım (Alan Yazın Ölçek Taraması): Diğer bir niteliksel adım olarak alan yazında yer alan ölçekler incelenmiştir. Alan yazında romantik ilişkilerde sosyal medya kıskançlığı ile ilgili olarak Muise, Christofides ve Desmarais (2009) tarafından geliştirilen ve Türk kültürüne uyarlaması Madran (2016) tarafından yapılan Facebook Kıskançlık Ölçeği bulunmaktadır. İlgili bu ölçek makalesi incelenmiş ve madde havuzu oluşturma sürecine katkı sağlanmıştır.

Ölçeğin hazırlanması sürecinde odak grup görüşmeleri, kompozisyon yazdırma ve alan yazın ölçek taraması gibi adımlar ölçek geliştirme sürecindeki "niteliksel adımları" oluşturur. Bu niteliksel adımlar sonucunda araştırmacılar tarafından madde havuzu oluşturulmuştur. Bu aşamada madde havuzundaki ifadeler araştırmacılar tarafından değerlendirilmiş ve romantik ilişkilerde sosyal medya kıskançlığını tanımlayan cümlelere dönüştürülmüştür.

4.Adım (Kapsam Geçerliği): Ölçek geliştirme sürecinde niteliksel adımlar kullanılarak aday ölçek formu geliştirilmiştir. Sosyal Psikoloji, Psikolojik Danışmanlık ve Rehberlik, İletişim-Halkla İlişkiler ve Tanıtım alanlarında çalışan toplam 9 uzman belirlenmiş ve aday ölçek formunu içeren uzman değerlendirme formu, bu uzmanlara elektronik ortamda değerlendirmek üzere e-mail yoluyla gönderilmiştir. Uzmanlardan; aday ölçek formundaki her bir maddenin, yapı ile ne derece ilgili (4: çok ilgili, 1: hiç ilgili değil) olduğunu ve söz konusu maddenin uygulanmak istenen hedef kitle için ne derece anlaşılır-açık (4: çok açık, 1: hiç açık değil) ve likert tipi düşünülen derecelendirme için ne derece uygun (4: çok uygun, 1: hiç uygun değil) olduğunu ilgili sayıyı işaretlemek üzere değerlendirmesi ve varsa yazılan maddeler hakkında öneri ve düzeltmelerini belirtmeleri istenmiştir.

Uzman değerlendirmeleri sonrasında kapsam geçerliği hesaplama çalışmasında Davis tekniği uygulanmıştır. Bu teknikte; uzmanların dört dereceli değerlendirmelerinde, (4) ve (3) seçeneğini işaretleyen uzmanların sayısı toplam uzman sayısına bölünerek maddeye ilişkin kapsam geçerlik indeksi (KGI) hesaplanmış ve kapsam geçerlik indeksi olarak 0.80 değeri ölçüt olarak kabul edilmiştir (Davis, 1992). Kapsam geçerliği çalışması sonucunda; 36.,38.,41. ve 42. maddeler olmak üzere dört madde uzman değerlendirmeleri sonrası, kabul edilen kapsam geçerlik in- 
deksi olan 80 ölçütünü sağlamadığı tespit edilmiştir. Uzman değerlendirmeleri sonrası, uzman değerlendirme formu- aday ölçek formundaki 2.madde; sosyal medya uygulamaları için genellenebilir özelliği açıklayan madde olmadığı için alanda çalışan, yayınları olan bir uzmanın tavsiyesiyle denemelik formdan çıkartılmışır. Uzman değerlendirme formundaki 38.madde ise araştırmacılar tarafından, sosyal medya uygulamaları için genellenebilir ve bu alandaki kıskançlı̆̆ olduğu düşünüldüğü için denemelik formdan çıkartılmamıştır. Özetle uzman değerlendirme ve kapsam geçerliği çalışması sonrasında dört madde aday ölçek formundan çıkartılmıştır. Sonuç olarak 57 maddelik formdan uzman değerlendirmeleri sonrası 53 madde kalmıştır. Araştırmacı tarafından; kapsam geçerliği sonrasında ölçekteki olumlu ve olumsuz ifadelerin, ölçme aracı içerisinde rastgele bir bicimde dağıtılmasına, düzenli bir sıra izlenmemesine ve gruplandırılmamasına dikkat edilerek (Karasar 1995, Tezbaşaran 1997, Kırcaali İftar, 1999) denemelik form oluşturulmuştur.

5.Adım (Ölçeğin Denemelik Formun Örnekleme Uygulanması): Uzman değerlendirme sonrası kapsam geçerlik yapılmış ve 53 maddelik beşli likert ("Bana tamamen uygun”, “Bana uygun”, “Ortadayım”, "Bana uygun değil", "Bana hiç uygun değil") olarak denemelik ölçek formu oluşturulmuştur. Bu denemelik ölçek formu, herhangi bir romantik ilişki yaşayan veya yaşamış olan bireylere yönelik uygulanmıştır. Ölçeği 18-56 yaş arasındaki 417 birey cevaplamıştır.

\section{Adım (Açımlayıcı ve Doğrulayıcı Faktör Analizlerinin Yapılması):} Bulgular kısmında açıklanmıştır. Açımlayıcı Faktör Analizi (AFA) yapılmadan önce veriler; örneklem büyüklügü ve kayıp veri, aykırı değerler, doğrusallık, normallik, çoklu bağlantı problemi, R'nin faktörlenebilirliği açısından faktör analizi için uygun hale getirilmiştir. AFA yapıldıktan sonra ayrıca DFA için de veriler bu sayıltılar ile test edilmiştir. 


\section{Verilerin Analizi ve Faktör Analizi Öncesinde Sayıltıların Test Edil- mesi}

Bu çalışmada; geliştirmek istenen romantik ilişkilerde sosyal medya kıskançlık ölçeğinin örtük yapısını ortaya koymak ve bu ölçeğe ait maddelerin kaç boyut(faktör) altında toplanabileceğini, aralarında nasıl bir ilişki olduğunu ortaya koymak amacıyla açımlayıcı faktör analizi (AFA) yapılmıştır. Açımlayıcı faktör analizi (AFA) yapılmadan önce veriler sayıltılar ile test edilerek analiz için uygun hale getirilmiştir. Açımlayıcı faktör analizi ile ölçek maddelerine ait açıklanan varyans sonuçları hesaplanmış; ardından çeşitli kriterler göz önünde bulundurularak faktör sayısı belirlenmiş ve faktör yük değerleri hesaplanmıştır. Faktör sayıs1nın belirlenmesinden sonra döndürme gerçekleştirilmiş ve döndürme sonrası yük değerleri hesaplanmıştır. Açımlayıcı faktör analizi sonrasında ölçeğin iç tutarlılık anlamında güvenirlik değerini ortaya koyan Cronbanch Alfa güvenirlik analizi katsayıları hesaplanmıştır.

Öte yandan ölçeğin psikolojik yapı geçerliğini ortaya koymak amacıyla yeniden veri toplama yoluna gidilerek doğrulayıcı faktör analizi yapılmıştır. Dfa ile ölçeğin faktörlerine ait standardize yük değerleri ve kestirilen hata varyansları, ölçeğin tüm maddelerine ilişkin ise T değerleri incelenmiş ve son olarak doğrulayıcı faktör analizine ilişkin uyum iyiliği değerleri hesaplanmıştır. Doğrulayıcı faktör analizi sonrasında ölçeğin iç tutarlılık anlamında güvenirlik değerini ortaya koyan Cronbanch Alfa güvenirlik analizi katsayıları hesaplanmıştır.

\section{Açımlayıcı Faktör Analizi İçin Sayıltıların Test Edilmesi}

Örneklem büyüklüğ̈̈ ve kayıp veri açısından incelendiğinde; Comrey ve Lee (1992), faktör analizinde yeterli örneklem büyüklüğü için 50'nin çok zayıf, 100'ün zayıf, 300'ün iyi, 500'ün çok iyi ve 1000'in mükemmel olduğunu açıklamaktadır. Guilford'a göre (1954) örneklem sayısı için en az 200 olması gerekliliğini belirtmiştir. Kline (1994) ise faktör analizi için 200 kişilik bir örneklemin yeterli sayılabileceğini ifade etmiştir. Child (2006)'ya göre madde sayısının 4 ya da 5 katı, Tavşancıl'a göre (2002) ise madde sayısının 5 ile 10 katı arasında örneklem hacmi için yeterli olmaktadır. Tabachnick ve Fidell (2015) ise minimum gözlem sayısının 300 
olması gerektiğini ifade etmiştir. Tüm bunlar göz önüne alındığında, bu araştırmadaki örneklem büyüklügünün yeterli olduğu görülmektedir. Araştırmadaki veriler, kayıp veri yönünden incelenmiş olup herhangi bir kayıp veriye rastlanmamıştır. Aykırı Değerler açısından incelediğimizde verilerin aykırı değerleri (uç değerlerini) bulmak amacıyla $Z$ değerleri ve mahalanobis uzaklıkları incelenmiştir. $Z$ değeri incelendiğinde +3 ile -3 aralığı dışında kalan üç aykırı değer $(202,208,274)$ olduğu görülmüştür. Tabachnick ve Fidell'e göre(2001) $\mathrm{Z}$ değerlerinin +3.29 ile -3.29 arasında değerler olması gerekmektedir. Mertler ve Vannatta (2005) örneklemin 100 'ün üzerinde olduğu geniş örneklemlerde Z puanları +4 ile -4 aralığı olarak genişletilebileceği belirtmektedir. Tüm bu ölçütler göz önüne alındığında; 417 gözlemdeki en uç $Z$ değerlerin -2.70 ile 3.54 değerleri olduğu göz önüne alındığında verilerde tek değişkenli aykırı değerler olmadığı görülmektedir. Ki kare dağılımı esas alınarak, maddelerin Mahalanobis değerleri .001 ve daha düşük olan değerler çoklu değişken aykırı değerler incelendiğinde $\left(\chi^{2} 53 ; 0,001=90.57\right) 31$ gözlem Mahalanobis değerlerini karşılamadığı için analize dahil edilmeyerek, geriye kalan toplam 386 gözlemden elde edilen veriler ile analizler yürütülmüştür. Doğrusallık sayıltısında birbirinden en uzaktaki iki madde arasındaki saçılım grafiği incelenmiştir. Bu saçlım grafiğinde doğrusallığın kesin kanıtı olmamasına rağmen doğada iki değişken arasında doğrusal ilişkiyi yakalamak zor olduğundan analizler madde çiftleri arasındaki korelasyonun doğrusal olduğu sayıltısıyla devam edilmiştir. Normallik sayıltısında 53 madde için normallik dağılım ölçütlerine uyup uymadığı konusunda maddeler tek tek incelenmiştir. Çalışmadaki verilerin normal dağılıp dağılmadığı tek değişkenlerin istatistik yöntemlerinden merkezi eğilim ölçüleri ve basıklık-çarpıklık değerleri ile kontrol edilmiştir. 53 maddelik aday ölçek formundaki ortalama, ortanca ve tepedeğer birbirlerine genellikle yakın oldukları için tek değişkenli normallik dağılım özelliği sergilemektedir (Can, 2018, s.82). 53 maddenin tek tek skewness(çarpıklık) ve kurtosis(basıklık) değerleri incelendiğinde; skewness değerlerinin -1.065 ile 2.239 arasında değerler aldığ 1 ve kurtosis değerlerinin -1.149 ile 5.032 arasında değerler aldığ görülmektedir. $\mathrm{Bu}$ değerler göz önüne alındığında ve çarpıklık katsayısının -3.3 ile +3.3 ve basıklık katsayısı -7 ile +7 arasında değerler almasının normallik koşullarını sağlaması (Bernstein, 2000) nedeniyle normalliğin sağlandığı 
görülmektedir. Çoklu bağlantı problemi için Tolerans ve VIF değerlerine bakılmıştır. Maddeler arasındaki Tolerans değerleri .241 ile .631 arasında; VIF değerleri ise 1.631 ile 4.150 arasında değerler almaktadır. Maddeler incelendiğinde Tolerans değerleri $>0.20$ ve VIF değerleri $<5$ olduğundan çoklu bağlantı problemi olmadığı görülmüştür. Tüm maddelere ilişkin sağlanan Durbin-Watson değerinin ise 1.927 olduğu için (DW $\leq 2$ $\leq 2.5)$ hatalarn otokorelasyonu söz konusu değildir; hatalar birbirinden bağımsızdır (Kalaycı, 2005). R'nin faktörlenebilirliği açısından incelendiğinde veri setine faktör analizi uygulanabilirliğinin test edilmesi amacıyla KMO (Kaiser-Meyer-Olkin) "Örnekleme Yeterliliğinin Ölçümü Testi" ve Bartlett'in (Bartlett's Test of Sphericity) "Küresellik Testi"nden yararlanılmaktadır. KMO değerinin 0,60 ve üstünde olması, örneklemin faktör analizi için yeterli olacağına işaret etmekteyken, Hutcheson ve Sofroniou (1999) bu değerin 0.5 ile 0.7 arasının normal; 0.7 ile 0.8 arasının iyi; 0.8 ile 0.9 arasının çok iyi; 0.9 ve üzerinin ise mükemmel olduğunu belirtmektedir (Dağll, 2015, s.205). Bartlett'in küresellik testi ise korelasyon matrisindeki ilişkilerin faktör analizi yapacak ölçüde yeterli olup olmadığını test etmektedir. Bu test sonucunun anlamlı olması $(\mathrm{p}<0.05)$ değişkenler arası ilişkilerin oluşturduğu matrisin faktör analizi için anlamlı olduğunu ve faktör analizi yapılabileceğini göstermektedir (Gürbüz ve Şahin, 2016, s.311).

Tablo 1. KMO ve Bartlett Testi

\begin{tabular}{lll}
\hline KMO ve Bartlett Testi & & \\
\hline Kaiser-Meyer-Olkin Örnekleme Yeterliliğinin Ölçümü & & .952 \\
\hline Bartlett'in Küresellik Testi & Yaklaşık Ki-Kare & 13437.780 \\
\cline { 2 - 3 } & Sff & 1378 \\
\hline
\end{tabular}

KMO testi neticesinde örneklem yeterlilik değerinin 0.952 olduğu ve örneklem büyüklüğünün faktör analizi için "mükemmel" derecede (Kalayc1, 2014) uygun olduğu bulgusu elde edilmiştir. Ayrıca, Bartlett küresellik testinin anlamlı olması $[\chi 2(1378)=13437.780, \varrho<0.01]$ maddeler arasındaki korelasyon ilişkilerinin faktör analizi için uygun olduğunu göstermektedir. 


\section{Doğrulayıcı Faktör Analizi İçin Sayıltıların Test Edilmesi}

RİSMKÖ psikolojik yapı geçerliğini incelemek amacıyla doğrulayıcı faktör analizi (DFA) uygulanmıştır. DFA uygulama öncesinde; açımlayıcı faktör analizi sonrasında oluşan 21 maddelik nihai form ile yeniden veri toplama yoluna gidilmiş ve 332 bireye ulaşılmıştır. Doğrulayıcı faktör analizi yapılmadan önce yine sayıltılar (örneklem büyüklüğü, kayıp değerler, doğrusallık, normallik, çoklu bağlantı problemi ve hataların otokorelasyonu, R'nin faktörlenebilirliği) test edilmiştir.

Örneklem büyüklü̈̆̈̈ ve kayıp veri açısından incelendiğinde; Child (2006)'ya göre madde sayısının 4 ya da 5 katı, Tavşancıl'a göre (2002) ise madde sayısının 5 ile 10 katı arasında örneklem hacmi için yeterli olmaktadır. Tabachnick ve Fidell (2015) ise minimum gözlem sayısının 300 olması gerektiğini ifade etmiştir. Tüm bunlar göz önüne alındığında, bu araştırmadaki örneklem büyüklügünün yeterli olduğu görülmektedir. Doğrulayıcı faktör analizi için toplanan veriler, kayıp veri yönünden incelenmiş olup herhangi bir kayıp veriye rastlanmamıştır. Normallik sayıltısı, nihai formda 21 madde için normallik dağılım ölçütlerine uyup uymadığı konusunda maddeler tek tek incelenmiş olup doğrulayıcı faktör analizi için toplanan verilerin normal dağılıp dağılmadığı tek değişkenlerin istatistik yöntemlerinden merkezi eğilim ölçüleri ve basıklıkçarpıklık değerleri ile kontrol edilmiştir. 21 maddelik ölçek formundaki ortalama, ortanca ve tepedeğer birbirlerine genellikle yakın oldukları için tek değişkenli normallik dağılım özelliği sergilemektedir (Can, 2018, s.82). 21 maddenin tek tek skewness(çarpıklık) ve kurtosis(basıklık) değerleri incelendiğinde; skewness değerlerinin -1.061 ile 1.950 arasında değerler aldığ 1 ve kurtosis değerlerinin -1.248 İle 3.444 arasında değerler aldığ 1 görülmektedir. Bernstein'e göre (2000) çarpıklık katsayısının -3.3 ile +3.3 ve basıklık katsayısı -7 ile +7 arasında değerler alması normallik sayıltısını karşılaması nedeniyle normalliğin sağlandığı görülmektedir. Aykırı Değerler açısından incelediğimizde, verilerin aykırı değerleri(uç değerlerini) bulmak amacıyla $\mathrm{Z}$ değerleri ve mahalanobis uzaklıkları incelenmiştir. Tabachnick ve Fidell'e göre(2001) Z değerlerinin +3.29 ile 3.29 arasında değerler olması gerekmektedir. Mertler ve Vannatta (2005) örneklemin 100'ün üzerinde olduğu geniş örneklemlerde $\mathrm{Z}$ puanları +4 ile -4 aralığ1 olarak genişletilebileceği belirtmektedir. Tüm bu ölçütler 
göz önüne alındığında; 322 gözlemdeki en uç $Z$ değerlerin -3.36 ile 3.44değerleri olduğu göz önüne alındığında verilerde tek değişkenli aykırı değerler olmadığı görülmektedir. Ki kare dağılımı esas alınarak, maddelerin Mahalanobis değerleri .001 ve daha düşük olan değerler çoklu değişken aykırı değerler incelendiğinde $\left(\chi^{221 ; 0,001=46.80}\right) 13$ gözlem Mahalanobis değerlerini karşılamadığ 1 için analize dahil edilmeyerek, geriye kalan toplam 309 gözlemden elde edilen veriler ile analizler yürütülmüştür. 309 gözlem 300 gözlemden büyük olduğu için doğrulayıcı faktör analizi yapılması uygun görülmektedir. Çoklu bağlantı problemi için Tolerans ve VIF istatistikleri ile incelenmiştir. Maddeler arasındaki Tolerans değerleri .272 ile .602 arasında; VIF değerleri ise 1.661 ile 3.676 arasında değerler almaktadır. Maddeler incelendiğinde Tolerans değerleri $>0.20$ ve VIF değerleri $<5$ olduğundan çoklu bağlantı problemi olmadığ 1 görülmüştür. Tüm maddelere ilişkin sağlanan Durbin-Watson değerinin ise 1.811 olduğu için (DW $\leq 2 \leq 2.5$ ) hataların otokorelasyonu söz konusu değildir; hatalar birbirinden bağımsızdır (Kalaycı, 2005). $R^{\prime}$ nin faktörlenebilirliği açısından incelendiğinde; veri setine faktör analizi uygulanabilirliğinin test edilmesi amaciyla KMO (Kaiser-MeyerOlkin) "Örnekleme Yeterliliğinin Ölçümü Testi" ve Bartlett'in (Bartlett's Test of Sphericity) "Küresellik Testi"nden yararlanılmaktadır. KMO testi neticesinde örneklem yeterlilik değerinin 0.906 olduğu ve örneklem büyüklüğünün faktör analizi için "mükemmel" derecede (Kalaycı, 2014) uygun olduğu bulgusu elde edilmiştir. Ayrıca, Bartlett küresellik testinin anlamlı olmas1 $[\chi 2(210)=3758.606, \varrho<0.01]$ maddeler arasindaki korelasyon ilişkilerinin faktör analizi için uygun olduğunu göstermektedir. Doğrulayıcı faktör analizinin bütün sayıltılarını tamamladıktan sonra 309 gözlem ve 21 madde ile doğrulayıcı faktör analizi uygulanmıştır.

\section{Bulgular}

\section{Açımlayıcı Faktör Analizi}

Açımlayıcı faktör analizinin bütün sayıltılarını tamamladıktan sonra 386 gözlem ve 53 madde ile faktör analizi uygulamalarına başlanılmıştır. 


\section{Açıklanan Varyans Sonuçları}

Maddelerin açıklanan varyans değerleri tablosu incelendiğinde; maddelerin açılanan varyans değerlerinin .499 ile .792 arasında değerler aldığ 1 görülmektedir. Ölçüt olarak ele aldığımız açılanan varyansın .30'un altında herhangi bir madde olmadığı görülmektedir. Maddelerin ortak faktör varyanslarının genellikle yüksek olduğu görülmektedir fakat maddelerin ortak varyans değerleri düşük olsa bile; bu tabloya bakılarak maddeler hakkında kesin karar verilmesi uygun değildir. Dolayısıyla maddelerin işleyip işlemedikleri konusunda ilerleyen tablolar ile değerlendirme yapmak yerinde olacaktır (Çokluk, Şekercioğlu ve Büyüköztürk, 2018, s.229).

\section{Faktör Sayısının Belirlenmesi}

İkinci aşamada faktör sayısının belirlenmesine yönelik çeşitli kriterler bulunmaktadır. Bu çalışmada da bu kriterlerden "Kaiser Kriteri” , "Açılanan Varyans Kriteri" , "Yamaç-Eğim Grafiği” ,"Toplam Varyansın Yüzdesi Metodu" kriterleri incelenmiştir.

Tablo 2. Açıklanan Varyans Tablosu

\begin{tabular}{|c|c|c|c|c|c|c|c|c|c|}
\hline \multirow[t]{2}{*}{ Bileşen } & \multicolumn{3}{|c|}{ Başlangıç Özdeğerler } & \multicolumn{3}{|c|}{$\begin{array}{l}\text { Karesi alınan yüklerin toplam } \\
\text { çıarımı }\end{array}$} & \multicolumn{3}{|c|}{$\begin{array}{l}\text { Karesi alınan yüklerin döndür- } \\
\text { me toplamı }\end{array}$} \\
\hline & Toplam & $\begin{array}{l}\text { Varyans } \\
\%\end{array}$ & $\begin{array}{l}\text { Birikimli } \\
\%\end{array}$ & Toplam & Varyans $\%$ & $\begin{array}{l}\text { Birikimli } \\
\%\end{array}$ & Toplam & Varyans \% & $\begin{array}{l}\text { Birikimli } \\
\%\end{array}$ \\
\hline 1 & 20,122 & 37,966 & 37,966 & 20,122 & 37,966 & 37,966 & 5,858 & 11,053 & 11,053 \\
\hline 2 & 3,341 & 6,304 & 44,271 & 3,341 & 6,304 & 44,271 & 4,525 & 8,538 & 19,591 \\
\hline 3 & 2,714 & 5,121 & 49,391 & 2,714 & 5,121 & 49,391 & 4,189 & 7,905 & 27,495 \\
\hline 4 & 1,696 & 3,200 & 52,591 & 1,696 & 3,200 & 52,591 & 4,162 & 7,853 & 35,348 \\
\hline 5 & 1,532 & 2,891 & 55,483 & 1,532 & 2,891 & 55,483 & 3,635 & 6,858 & 42,206 \\
\hline 6 & 1,332 & 2,513 & 57,996 & 1,332 & 2,513 & 57,996 & 3,010 & 5,679 & 47,885 \\
\hline 7 & 1,192 & 2,248 & 60,244 & 1,192 & 2,248 & 60,244 & 2,880 & 5,434 & 53,318 \\
\hline 8 & 1,130 & 2,133 & 62,377 & 1,130 & 2,133 & 62,377 & 2,600 & 4,905 & 58,223 \\
\hline 9 & 1,084 & 2,046 & 64,422 & 1,084 & 2,046 & 64,422 & 2,592 & 4,891 & 63,114 \\
\hline 10 & 1,073 & 2,024 & 66,446 & 1,073 & 2,024 & 66,446 & 1,766 & 3,332 & 66,446 \\
\hline
\end{tabular}




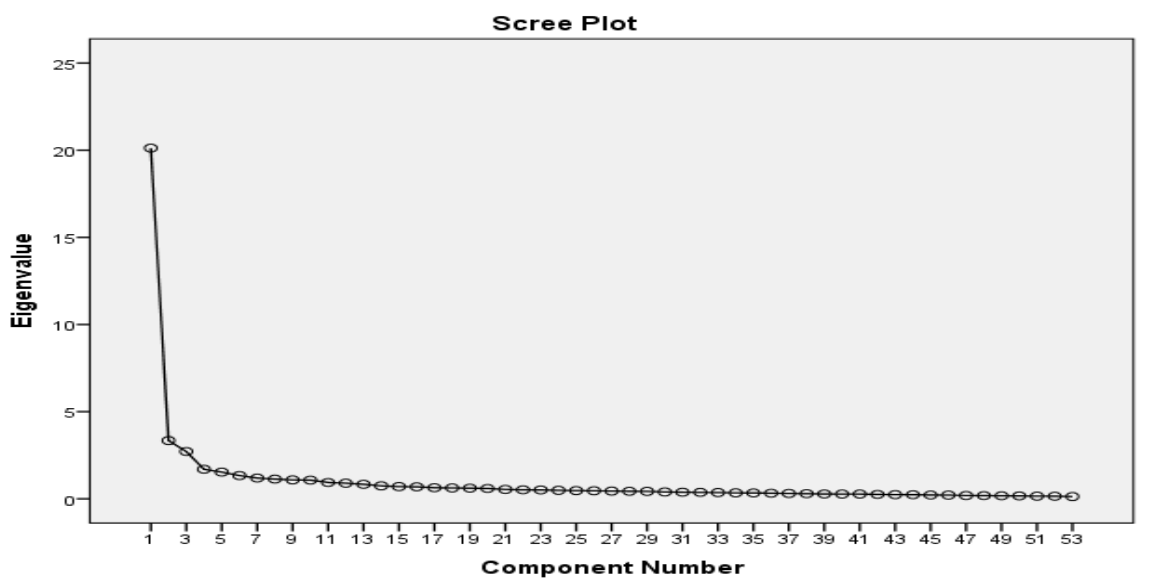

Şekil 1. Yamaç Ĕ̆im Grafiği

Literatürde en yaygin kullanılan tekniklerden biri olan Kaiser kriterine göre öz değerin 1'den büyük olmasına dayalı olan bir metottur. Tablo incelendiğinde; öz değeri 1'in üzerinde olan 10 faktör bulunmaktadır. Fakat bu metod objektiflik ve bazı hususlarda eleştiriler alması nedeniyle faktör sayısı kara verilirken diğer kriterler de incelenmiştir. Açıklanan Varyans Kriteri ele alındığında Scherer, Wiebe, Luther ve Adams'a göre, sosyal bilimlerde açıklanan varyansın $\% 40$ ile $\% 60$ arasında olması yeterli olarak kabul edilir (Akt: Tavşancıl, 2005). Diğer bir kriter olarak Yamaç Eğim Grafiği Şekil 1'de gösterilmektedir. Grafik incelendiğinde iki nokta arasındaki uzaklığın faktör olarak kabul edildiği ve 4.noktadan itibaren grafik çizgilerinin plato yaptığı görülmekte ve sonuç olarak yamaç eğim grafiğine göre 3 faktörlü bir yapının oluşabileceği görülmektedir. Dördüncü kriter olarak Toplam Varyansın Yüzdesi Metodu ile her ilave faktörün toplam varyansın açıklanmasına katkısının \%5'in altına düştüğünde maksimum faktör sayısına ulaşılmış olacağ1 (Kalaycı, 2005, s.322) göz önüne alındığında ve Tablo 2 incelendiğinde ilk 3 faktörün bu kriteri sağladığı, 4.faktör itibariyle katkının \%5' in altına düştüğü; sonuç olarak bu kritere göre 3 faktörlü bir yapının oluştuğu görülmektedir. Faktör sayısının belirlenmesine yönelik "Kaiser Kriteri" , "Açıklanan Varyans Kriteri" , "Yamaç-Eğim Grafiği" ve "Toplam Varyansın Yüzdesi Metodu" bağlamında dört kriter ayrı ayrı incelenmiş ve sonuç olarak üç faktörlü bir yapının oluştuğu tespit edilmiştir. 


\section{Döndürme Aşaması ve Faktör İsimlendirilmesi}

Üçüncü aşamada üç faktörlü yapı oluşturularak ve "varimax" döndürme işlemi seçilerek tekrardan Açımlayıcı faktör analizi yapılmıştır. 386 gözlemdeki ikili değişkenler arasındaki korelasyonlar incelendiğinde olası faktörler arasında anlamlı bir korelasyon yoktur. Yani faktörler ilişkisizdir ve dolayısıyla "dik dördüme" tekniklerinden yararlanılır. Faktörler birbirleriyle ilişkisiz olduğu için açılanan varyansı maximize eden bir teknik kullanılması uygun görülmüş ve "varimax" dik döndürme tekniğinden yararlanılmıştır.

386 gözlem ve 53 madde ile yapılan faktör analizinde; döndürülmüş bileşenler matrisi incelendiğinde 8 maddenin binişik (10.11.16.17.21.28.40.41.maddeler) ve 4 maddenin faktör yük değerini sağlamadığı (3.6.13.52.maddeler); ayrıca bir maddenin (29.madde) ölçüt olarak ele aldığımız açıklanan varyansın .30 'un altında olduğu görülmüştür. Bu maddeler analizden çıkartılarak kalan toplam 40 madde ile tekrar faktör analizi gerçekleştirilmiştir.

Tekrarlanan bu faktör analizi işlemi sonrası açıklanan varyans oranlarının üç faktörde toplam \%50.776 olduğu ve yamaç eğim grafiğinin üç faktörde daha da keskinleştiği görülmektedir. Yapılan bu faktör analizinde 2 maddenin (4. ve 32. Madde) faktör yük değerini sağlamadığ 1 görülmekte analizden çıkartılarak faktör analizi tekrar yapılmıştır.

Daha iyi bir faktör analizi ve daha iyi bir sonuç vermesi açısından faktör yük değerleri .60 kriteri bazında değerlendirilmiş olup bu kriteri sağlamayan 17 madde (faktör 1'deki: 36., 43., 39., 25., 23., 24., 5., 19.maddeler; faktör 2'deki:31., 46., 7., 12., 45., 15.maddeler; faktör3'teki:53., 38., 51. maddeler) analizden çıkartılarak tekrardan faktör analizi işlemi uygulanmıştır. Bu işlem sonucunda açıklanan varyansın daha da arttığ1 (3 faktörde toplam \%58.467) ve yamaç eğim grafiğinin daha da keskinleşerek 4.noktadan itibaren plato oluşturduğu daha da net görülmektedir. Son olarak yapılan bu işlemde 21 maddeden oluşan üç faktörlü bir yapı ortaya konulmuştur. Bu yapıya ilişkin faktör yükleri, ortak faktör varyansları vb. bilgiler aşağıdaki Tablo 3'te yer almaktadır. 
Tablo 3. Ölçeğe Ait Faktör Yükleri ve Ortak Faktör Varyansları

\begin{tabular}{|c|c|c|c|c|}
\hline $\begin{array}{l}\text { Aday Ölçek } \\
\text { Madde nu. }\end{array}$ & Faktör 1 & Faktör 2 & Faktör 3 & Ortak Faktör Varyansı $\left(h^{2}\right)$ \\
\hline 14 & 0,743 & & & 0,592 \\
\hline 26 & 0,716 & & & 0,612 \\
\hline 27 & 0,713 & & & 0,585 \\
\hline 18 & 0,707 & & & 0,546 \\
\hline 30 & 0,692 & & & 0,537 \\
\hline 50 & 0,650 & & & 0,454 \\
\hline 2 & 0,649 & & & 0,511 \\
\hline 22 & 0,639 & & & 0,494 \\
\hline 37 & 0,626 & & & 0,596 \\
\hline 33 & & 0,770 & & 0,619 \\
\hline 9 & & 0,782 & & 0,685 \\
\hline 20 & & 0,739 & & 0,558 \\
\hline 42 & & 0,734 & & 0,603 \\
\hline 8 & & 0,720 & & 0,677 \\
\hline 1 & & 0,681 & & 0,583 \\
\hline 48 & & & 0,828 & 0,729 \\
\hline 47 & & & 0,778 & 0,637 \\
\hline 35 & & & 0,739 & 0,596 \\
\hline 44 & & & 0,707 & 0,534 \\
\hline 34 & & & 0,705 & 0,516 \\
\hline 49 & & & 0,637 & 0,612 \\
\hline $\begin{array}{l}\text { Açıklanan } \\
\text { Varyans }\end{array}$ & $\% 37.259$ & $\% 11.731$ & $\% 9.476$ & \\
\hline $\begin{array}{l}\text { Cronbach } \\
\text { Alfa }\end{array}$ & .886 & .871 & .859 & \\
\hline
\end{tabular}

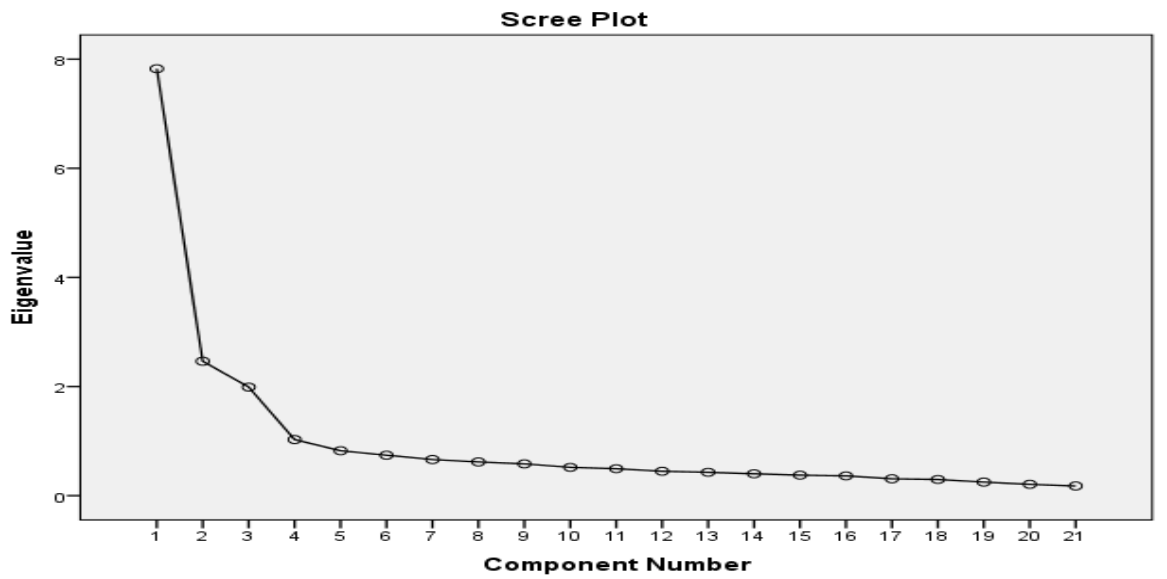

Şekil 2. Açımlayıcı Faktör Analizi Sonrasında Oluşan Yamaç Ĕ̆im Grafiği 
İlgili alan yazın ve uzman önerileri doğrultusunda faktör isimlendirilmeleri yapılmış ve 9 maddeden oluşan birinci faktör "Kısıtlayıcı ve Kontrolcü Tutum"; 6 maddeden oluşan ikinci faktör "Şüpheci ve Gözetleyici tutum"; 6 maddeden oluşan üçüncü faktör "Sosyal Medya Alanına Saygı ve Güven" olarak adlandırılmıştır.

\section{Romantik İlişkilerde Sosyal Medya Kıskançlığı Ölçeği AFA Sonrası Güvenirlik Analizi Sonuçları}

Mevcut araştırmada; 386 gözlem ve 21 maddelik nihai ölçek üzerinden elde edilen Cronbach Alfa güvenirlik analizi katsayıları; ölçeğin tamamı için .912, birinci faktör için .886, ikinci faktör için .871, üçüncü faktör için .859 olarak hesaplanmıştır.

\section{Doğrulayıcı Faktör Analizi}

Yapılan DFA sonucunda; "Kısıtlayıcı ve Kontrolcü Tutum" örtük değişkenine ait standardize yük değerleri 0.55 ile 0.79 arasında; "Şüpheci ve Gözetleyici Tutum" örtük değişkenine ait standardize yük değerleri 0.59 ile 0.88 arasında ve "Sosyal Medya Alanına Saygı ve Güven" örtük değişkenine ait standardize yük değerleri 0.68 ile 0.78 arasında değişmektedir. Bu değişkenlere ilişkin kestirilen hata varyansları "Kısıtlayıcı ve Kontrolcü Tutum" da 0.38 ile 1.04 arasında; "Şüpheci ve Gözetleyici Tutum"da 0.41 ile 0.76 arasında ve "Sosyal Medya Alanına Sayg1 ve Güven" boyutunda 0.71 ile 0.91 arasında değişmektedir. Bu üç örtük değiş̧kendeki tüm maddelerin $T$ değerleri incelendiğinde 2 'den büyük değerler aldığı ve bu değerlerin anlamlı olduğu görülmektedir. Yani özetle bütün maddeler ayırt edicidir. Standardize yük değerlerinin yanısıra tüm T değerlerinin de anlamlı olduğu göz önüne alındığında ölçme aracında yer alan 21 maddenin de ayırt edici-geçerli olduğu görülmektedir.

Analizin bu aşamasında; modifikasyon önerilerinin incelenmesinde fayda olduğu görülmektedir. Çıktı dosyasında yer alan modifikasyon önerileri incelendiğinde KISIT7 (Partnerimin, sosyal medya hesabına açtı̆̆ım sahte profilden mesaj atarm.) ile KISIT4 (Partnerimin, sosyal medya hesabm incelemek için sahte bir hesap oluştururum.) arasında yapılacak modifikasyonun $\chi 2$ 'ye önemli ölçüde katkı sağlayacağı görülmektedir. KISIT7 ile 
KISIT4 arasında yapılacak modifikasyon ile 777.70 olan $\chi 2$, 659.3'e düşecektir (777.70-118.4=659.3); bu durumda $\chi 2 /$ sd başta olmak üzere pek çok uyum indekslerinde bir iyileşme olacağı görülmektedir. Daha sonra yine öneriler doğrultusunda KISIT13 (Partnerimin, sosyal medya hesabını kapatmasını isterim.) ile KISIT2 (Partnerimin, sosyal medya hesabr kullanmasin istemem.) arasında, SUPHE5 (Partnerimin, sosyal medyada paylaştığı fotoğrafları beğenen sosyal medya hesapların incelerim.) ile SUPHE8 (Partnerimin, sosyal medyada paylaştı̆̆ fotoğraflara yorum yapan hesapları incelerim.) arasinda ve KISIT16 (Partnerimin, benimle birlikte ortak bir sosyal medya hesabr açmasını isterim.) ve KISIT10 (Partnerimin, sosyal medya hesabına ilişkimizle ilgili detaylar -tarih ve isim- yazmasin isterim.) arasında modifikasyon yapılmıştır. Bu modifikasyon sonrasında elde edilen bulgular incelendiğinde $\chi 2=537.52$ ve sd=182 olduğu görülmekte ve bu değerler birbirine oranlandığında ( $\chi 2 / \mathrm{sd}) 2.95$ değeri sonuçlanmış olup bu değerin 3'ün altında olmasının mükemmel uyumu ifade ettiği görülmektedir (Kline, 2005; Sümer,2000). Yol şemasında RMSEA değerine baktığımızda ise görülen .078 değerinin .08 'den küçük olmasından dolayı uyumun iyi olarak değerlendirilmesi mümkündür. Modifikasyon sonrasında elde edilen uyum indeksleri incelendiğinde NFI=.95 , NNFI=.96 CFI=.96 değerlerinin .95 'e eşit veya bu değerlerin üzerinde olmasının ve standardize edilmiş RMR değerinin (.069) ise .08' in altında olması iyi uyuma karş1lık gelmektedir. GFI değerinin .086 olması ise kabul edilebilir bir uyuma karşılık geldiği görülmektedir (Gürbüz ve Şahin, 2016; Jöreskog ve Sorbom, 1993; Meydan ve Şeşen, 2015). Bu çerçevede Romantik İlişkilerde Sosyal Medya Kıskançlığ1 Ölçeğinin 21 maddeden oluşan 3 faktörlü yapısının bir model olarak doğrulandığı ifade edilebilir.

\section{Yakınsak Geçerlik, Iraksak Geçerlik ve Birleştirici Güvenirlik}

Romantik İlişkilerde Sosyal Medya Kıskançlığı Ölçeği'nin doğrulanan psikolojik yapı geçerliği sonrasında; faktörlere ilişkin ortalama açıklanan varyans (AVE), maksimum paylaşılan varyansın karesi (MSV), maksimum paylaşılan varyansın karesinin ortalaması (ASV) ve birleştirici güvenirlik değerleri (CR) aşağıda tablo 4 'te verilmiştir. DFA sonucu ortaya çıkan modelde yakınsak geçerlik için ölçeğin alt boyutlar bazında tüm $\mathrm{CR}$ değerlerinin AVE değerlerinden büyük olması ve AVE değerlerinin 
de $0.5^{\prime}$ ten büyük olması beklendiğinden (Yaşlığlu, 2017) dolayı alt boyutlar bazında değerler incelendiğinde genel anlamda ölçütlere uygun değerler olduğu görülmektedir. AVE değeri hesaplamalarında sadece Kısıtlayıcı ve Kontrolcü Tutum boyutunda değerin 0.45 olduğu görülmekte; fakat kabul edilebilir düzeyde düşük AVE değerleri kabul edilmektedir (Hatcher, 1994). Iraksak geçerlik için ise iki değerin (MSV ve ASV) hesaplanması gerekmekte olup MSV $<$ AVE ve ASV $<$ MSV ve AVE'nin karekökünün faktörlerarası korelasyondan büyük olması koşullarının sağlanması ölçütü göz önüne alındığında (Yaşlığlu, 2017) ölçeğin ıraksak geçerlik koşulunun sağlandığı görülmektedir. Ayrıca birleştirici güvenirlik değerleri (CR) incelendiğinde .70 ölçütünün sağlandığ 1 görülmektedir. Özetle; Tablo 4 incelendiğinde yakınsak geçerlik, ıraksak geçerlik ve birleştirici güvenirlik değerlerinin genel anlamda ölçütlere uygun değerler olduğu görülmektedir.

Tablo 4. Ölçeğe Ait Yakınsak Geçerlik, Iraksak Geçerlik ve Birleştirici Güvenirlik Değerleri

\begin{tabular}{lllll}
\hline Faktörler & AVE & MSV & ASV & CR \\
$\begin{array}{l}\text { Şüpheci ve Gözetleyici } \\
\text { Tutum }\end{array}$ & 0.55 & 0.43 & 0.33 & 0.84 \\
\hline Kısıtlayıcı ve Kontrolcü Tutum & 0.45 & 0.44 & 0.41 & 0.83 \\
\hline $\begin{array}{l}\text { Sosyal Medya Alanına } \\
\text { Saygi ve Güven }\end{array}$ & 0.55 & 0.38 & 0.30 & 0.81 \\
\hline Ölçütler & AVE $>.50$ & MSV<AVE & ASV<MSV & CR $>.70$ \\
& CR $>$ AVE & & & \\
\hline
\end{tabular}

\section{Romantik İlişkilerde Sosyal Medya Kıskançlı̆̆ı Ölçeği DFA Sonrası Cronbach Alfa Güvenirlik Analizi Sonuçları}

Mevcut araştırmada; 309 gözlem ve 21 maddelik nihai ölçek üzerinden DFA sonrasinda elde edilen Cronbach Alfa güvenirlik analizi katsayıları; ölçeğin tamamı için .922 , birinci faktör "Kısıtlayıcı ve Kontrolcü Tutum" için .878 , ikinci faktör "Şüpheci ve Gözetleyici Tutum" için .881 , üçüncü faktör "Sosyal Medya Alanına Saygı ve Güven" için .878 olarak hesaplanmıştır. 


\section{Sonuç}

Bu çalışmada; romantik ilişkilerde sosyal medya kıskançlığını belirlemeye yönelik üç faktörlü ve toplam 21 maddeden oluşan bir ölçek geliştirilmiştir. Ölçekten alınan puanların yüksekliği romantik ilişkilerde bireylerin partnerlerine yönelik sosyal medya kıskançlığının yüksek olduğu şeklinde yorumlanabilir.

Romantik İlişkilerde Sosyal Medya Kıskançlık Ölçeği (RISMKÖ), romantik ilişkilerde bireylerin partnerlerine yönelik sosyal medya kıskançlık düzeylerini ölçmek amaciyla geliştirilen ve üç alt boyuttan oluşan bir ölçme aracıdır. "Kısıtlayıcı ve Kontrolcü Tutum" alt boyutu, bireyin partnerine yönelik sosyal medyada kisitlayıcı ve kontrolcü bir tutum sergilemesi ile ilgili olup, toplam 9 maddeden oluşmaktadır. "Şüpheci ve Gözetleyici Tutum" alt boyutu, bireyin partnerine yönelik sosyal medyada şüpheci ve gözetleyici bir tutum sergilemesi ile ilgili toplam 6 maddeden oluşmaktadır. "Sosyal Medya Alanına Saygı ve Güven" alt boyutu, bireyin partnerine yönelik sosyal medyada alanına saygı ve güven içeren tutum sergilemesi ile ilgili olup toplam 6 maddeden oluşmaktadır. Ölçek toplam 21 maddeden oluşmakta olup bu çalışma sonucunda ölçekten alt boyutlar bazında puanlar elde edilmektedir.

Elde edilen literatür çalışmaları sonucunda sosyal medya kıskaçlığına yönelik ülkemizde geliştirilen bir ölçek çalışması olmadığ1 görülmekte olup sadece Muise ve arkadaşları (2009) tarafından geliştirilen ve Türk kültürüne uyarlaması Madran (2016) tarafından yapılan "Facebook Kıskançlık Ölçeği" bulunmaktadır. Bu noktada; bu çalışmanın da amacı doğrultusunda romantik ilişkilerde sosyal medya kıskançlığını ölçmeye yönelik psikometrik özellikleri test edilmiş bir ölçme aracı geliştirmektir. Sonuç olarak geliştirilen Romantik İlişkilerde Sosyal Medya Kıskançlığ1 Ölçeği (RİSMKÖ); elde edilen örneklem üzerinde Türk kültürüne uygun ve romantik ilişkilerde sosyal medya kıskançlı̆̆ını ölçmeye yönelik geçerli ve güvenilir bir şekilde ölçebilen bir ölçme aracıdır. 


\title{
EXTENDED ABSTRACT
}

\section{Scale of Social Media Jealousy in Romantic Relationships (SSMJRR): A Study of Reliability and Validity}

\author{
* \\ Yunus Emre Aydın- - Nezaket Bilge Uzun \\ Şahinbey Guidance and Research Center-Mersin Univesity
}

When the literature on jealousy is examined, it has been stated that jealousy is experienced among person in three types: friend jealousy, sibling jealousy and romantic jealousy. Friendship jealousy is the jealousy seen in communication with people other than family members, which manifests itself in the school, work and friend environment (Akan, 2019). Sibling jealousy is defined as a competition between siblings at the point of sharing parental love and interest, or an inexplicable emotional confusion (Yavuz, 2007; Akoğlu and Şipal, 2012). Romantic jealousy, on the other hand, is a negative complex emotion based on emotional intimacy that usually manifests itself in romantic relationships with the opposite sex (Tortamıs, 2014). In this study, especially romantic jealousy was discussed.

With social media being a part of daily life, it has been observed that the relationships in social media have become as important as face-toface communication. More importantly, from the point of view of romantic relationships, it is seen that the partners develop behavioral patterns such as the desire to learn each other's social media passwords, checking their friend lists, knowing where they are going and liking whose photos. In fact, these situations between couples; reveals how effective the use of social media is in couples' relationships. It can be said that this situation between couples is related to the feeling of jealousy (Alikılıç, Alikılıç and Özer, 2019; Tokunaga, 2011). Applications such as Facebook, Instagram, Twitter, which are among the most used social media applications today; today, it is considered as a trigger of jealousy and a cause of partner violence, for reasons such as providing opportunities for past relationships and providing a suitable environment for establishing al- 
ternative relationships. Partners in romantic relationships; it is observed that they display insecure and controlling behaviors such as spying on their partner by creating a fake account, adding someone of the opposite sex as a friend, and examining their partner's profile longer and more frequently (Gençer, Karadere, Okumuş and Hocaoğlu, 2018).

Social media jealousy in romantic relationships can be called the negative complex reaction that occurs with the widespread use of technology, the internet and then social media, which can damage the relationship between partners. Considering the advantages of using social media (easy to use, quick access, low cost or free, etc.) and with the constantly updated applications on social media, this situation is becoming more and more common among partners and assumes different roles. Partners who have recently experienced social media jealousy in romantic relationships; in addition to behaviors such as wanting to learn social media passwords, checking friends lists, getting information about where they go, checking the last online / active time, asking your partner to delete some photos, reviewing the accounts of his partner one by one, creating a different fake profile, etc. it is seen that they develop complex behavior patterns.

When the literature is examined, it is seen that there is no scale development study regarding social media jealousy in romantic relationships in our country. Muise, Christofides and Desmarais (2009) developed the "Facebook Jealousy Questionnaire" with its original name, and the adaptation study of this scale into Turkish culture was conducted by Madran (2016). Madran (2016) stated that besides realizing the adaptation of the Facebook Jealousy Scale, such adaptation studies provide the opportunity to make new researches and also function as a step to develop new scales specific to the culture. The aim of this study is to develop a validity and reliability assessment tool to measure social media jealousy in romantic relationships.

For this purpose, in the process of creating a candidate scale form "Qualitative steps" (focus group interviews, essay printing, literature scale scanning) and "qualitative steps" (validity and reliability analysis) were used. Items with content validity rate below .80 after expert evaluations were removed from the 57 -item form and 53 items remained. The 53-item and five-point likert-type trial scale form was applied to 417 in- 
dividuals between the ages of 18-56 who had or had a romantic relationship. The basic assumptions of Explanatory Factor Analysis (EFA) have been tested; As a result of EFA, a structure consisting of a total of 21 3-dimensional items, namely "Restrictive and Controlling Attitude", "Skeptical and Observant Attitude", and "Respect and Trust in the Field of Social Media", was obtained. In order to examine the psychological construct validity of Social Media Jealousy in Romantic Relationships Scale; With the final form consisting of 21 items formed after EFA, data were collected again with 332 individuals; Before CFA, assumptions were tested and confirmatory factor analysis (CFA) was performed. As a result of DFA; When the standardized load values of the subdimensions, the estimated error variances for the variables, the $T$ values of all items and the goodness of fit of the model were examined, it was found that the 3-factor structure of the scale consisting of 21 items was confirmed as a model. When the convergent validity, divergent validity and combining reliability values of the scale after CFA are examined, it is seen that the values are suitable for the criteria in general. Finally; Cronbach alpha internal consistency coefficient; .922 for the whole scale, .878 for "Restrictive and Controlling Attitude", .881 for "Skeptical and Observant Attitude", and .878 for "Respect and Trust in Social Media". When all these findings are examined it was concluded that it is a reliable and valid scale for measuring social media jealousy in romantic relationships.

Social Media Jealousy Scale in Romantic Relationships is a measurement tool developed to measure the social media jealousy levels of individuals towards their partners in romantic relationships, consisting of three sub-dimensions and a total of 21 items. The "Restrictive and Controlling Attitude" sub-dimension is about the restrictive and controlling attitude of the individual towards his partner on social media and consists of 9 items. The "Skeptical and Observant Attitude" sub-dimension consists of a total of 6 items about the individual's skeptical and observant attitude towards his partner on social media. The "Respect and Trust in the Field of Social Media" sub-dimension is about the individual's attitude of respect and trust towards his partner in social media and consists of 6 items. The scale consists of 21 items in total, and as a 
result of this study, scores are obtained on the basis of sub-dimensions from the scale.

As a result, the Social Media Jealousy Scale in Romantic Relationships is a valid and reliable measurement tool that is suitable for Turkish culture and can measure social media jealousy in romantic relationships on the sample obtained.

\section{Kaynakça/References}

Akan, Y. (2019). Arkadaş Kıskançlık Ölçeği'nin (AKÖ) geliştirilmesi: Geçerlik güvenirlik çalışması. Anemon Muş Alparslan Üniversitesi Sosyal Bilimler Dergisi, 7(5). 133-140.

Akoğlu, G. ve Şipal, R. F. (2012). Düşük sosyoekonomik düzeydeki çocuklara yönelik erken müdahale yaklaşımları: Dünyadan ve Türkiye'den uygulamalar. Journal of Society \& Social Work, 23(1), 213-224.

Alikılıç, Ö., Alikılıç, İ. ve Özer, A. (2019). Dijital romantizm: Y kuşağının romantik ilişkilerinde sosyal medyanın rolü üzerine bir araştırma. Erciyes İletişim Dergisi, Uluslararası Dijital Çağda İletişim Sempozyumu Özel Sayısı, 5780. DOI: 10.17680/erciyesiletisim. 485005.

Bernstein, I. (2000). Some consequences of violating SEM's assumptions. Paper presented at the annual meeting of Southwestern Psychological Association, Dallas, TX.

Can, A. (2018). SPSS ile bilimsel araştırma sürecinde nicel veri analizi. Ankara: Pegem Akademi.

Child, D. (2006), The essentials of factor analysis (3rd Edition). London: Continuum.

Comrey, A. L. ve Lee, H. B. (1992). A first course in factor analysis. Hillside, New Jersey: Lawrence Erlbaum Associates, Publishers.

Çokluk, Ö., Şekercioğlu, G. ve Büyüköztürk, Ş. (2018). Sosyal bilimler için çok değiş̧kenli istatistik: SPSS ve LISREL uygulamaları. Ankara: Pegem Akademi.

Dağll, A. (2015). Örgütsel Muhalefet Ölçeğinin Türkçe'ye uyarlanması: Geçerlik ve güvenirlik çalışması. Electronic Journal of Social Sciences, 14(53), 198218.

Davis, L. L. (1992). Instrument review: Getting the most from a panel of experts. Applied nursing research, 5(4), 194-197. 
Demirtaş-Madran, H. A. (2016). Facebook Kıskançlığı Ölçeğinin Türkçe formu: Üniversite öğrencileri üzerinde geçerlilik ve güvenilirlik çalışması. Anatolian Journal of Psychiatry, 17, 93-99.

Demirtaş, H. A. (2004). Yakın ilişkilerde kıskançlık: Bireysel, ilişkisel ve durumsal değiş̧kenler. Doktora Tezi. Ankara Üniversitesi, Sosyal Bilimler Enstitüsü, Psikoloji Ana Bilim Dalı, Ankara.

Dursun, Ö.Ö ve Barut, E. (2016). Sosyal medyanın yeni sorunsalı: Sanal kimlikler. Aytekin İşman, Hatice Ferhan Odabaşı, Buket Akkoyunlu (Ed.) Ĕğitim Teknolojileri Okumaları 2016 içinde (s.535-548). Ankara: Salmat.

Freud, S. (1998). Some neurotic mechanisms in jealousy, paranoia, and homosexuality. İçinde N. Burke (Ed.), Gender and Envy (s.213-220). New York: Routledge.

Gençer A.G., Karadere M.E., Okumuş B., Hocaoğlu Ç. (2018) DSM-5'e Giremeyen Tanılar (Kompulsif Satın Alma, Misophonia, Facebook Kıskançlığı, Pagofaji, Siberkondria, İnternet Bağımlılığı). Çiçek Hocaoğlu (Ed.) DSM-5'in Yeni Tanıları 2018 içinde (s.87-96) Ankara: Türkiye Klinikleri.

Guerrero, L. K., Spitzberg, B. H. ve Yoshimura, S. M.(2004). Sexual and emotional jealousy. The Handbook of Sexuality in Close Relationships. New Jersey: Lawrence Erlbaum Associates (LEA) Publishers.

Guilford, J. P. (1954). Psychometric methods. New York: McGraw- Hill Book Co.

Gürbüz, S. ve Şahin, F. (2016). Sosyal bilimlerde araştırma yöntemleri. Ankara: Seçkin Yayıncllk.

Hatcher L. (1994). A step-by-step approach to using the SAS system for factor analysis and structural equation modeling. Cary, NC: The SASInstitute.

Hutcheson, G. ve Sofroniou, N. (1999). The multivariate social scientist. London: Sage.

Jöreskog, K. G. ve Sörbom, D. (1993). Windows LISREL 8.12. Chicago: Scientific Software International.

Kalaycı, Ş. (2014). SPSS Uygulamaları çok değiş̧kenli istatistik teknikleri (6. Baskı). Ankara: Asil Yayınevi.

Kalaycı, Ş., Albayrak, A. S., Eroğlu, A., Küçüksille, E., Ak, B., Karaltı, M. ve Antalyalı, Ö. L. (2005). SPSS uygulamal çok değişkenli istatistik teknikleri. Ankara: Asil Yayın Dağıtım.

Karasar, N. (1995). Bilimsel araştırma yöntemi (7. Basım). Ankara: Sim Matbaası.

Kırcaali-İftar, G. (1999). Ölçme, sosyal bilimlerde araştırma yöntemleri. Eskişehir: Anadolu Üniversitesi Yayınları, s.11-22.

Kline, P. (1994) An easy guide to factor analysis. New York: Routledge. 
Korkmaz, A. (2012). Arap Baharı sürecinde internet ve sosyal medyanın rolü. International Symposium On Language And Communication Research Trends and Challenges (ISLC), 2147-2153.

Mathes, E.W. (1992) Jealousy: The psychological data. Lanham: University Press of America.

Mead M. (1977) Jealousy: Primitive and civilized. Jealousy, G Clanton, L G Smith (Ed), Englewood Cliffs, NJ. Prentice Hall, s.115-126.

Mertler, C. A. ve Vannatta, R. A. (2005). Advanced and multivariate statistical methods: Practical application and interpretation (third edition). United States: Pyrczak Publishing.

Meydan, C. M. ve Şeşen, H. 2015. Yapısal eşitlik modellemesi AMOS uygulamaları (2.Baskı). Ankara: Detay Yayıncılık.

Muise, A., Christofides, E. ve Desmarais S. (2009). More information than you ever wanted: Does facebook bringout the green-eyed monster of jealousy? Cyberpsychol Behav 12(4), 441-444.

Pines, A. (1998). Romantic jealousy: Causes, symptoms. Cures. NY: Routledge.

Pines, A. M. (2003). Aşk ve kıskançlık. (C. Yüksel, Çev.). İstanbul: Okuyan Us.

Sayımer, İ. (2008). Sanal ortamda halkla ilişkiler. İstanbul: Beta Yayınları.

Tavşancıl, E. (2002). Tutumlarm ölçülmesi ve SPSS ile veri analizi. Ankara: Nobel Yayıncilik.

Tavşancıl, E. (2005). Tutumların ölçülmesi ve SPSS ile veri analizi. (2. Baskı). Ankara: Nobel Yayın Dagitım.

Vural, Z. B. ve Bat, M. (2010). Yeni bir iletişim ortamı olarak sosyal medya: Ege Üniversitesi İletişim Fakültesine yönelik bir araştırma. Journal of Yaşar University, 5(20), 3348-3382.

Tabachnick, B. G. ve Fidell, L. S. (2001). Using multivariate statistics. (4th ed.) Boston: Allyn and Bacon.

Tabachnick, B. G. ve Fidell, L. S. (2015). Çok değişkenli istatistiklerin kullanımı. Ankara: Nobel Yayıncilik.

TDK. (2020). http://www.tdk.gov.tr (Erişim Tarihi: 1 Ağustos 2020).

Tezbaşaran, A. (1997) Likert tipi ölçek geliştirme kılavuzu (2. Basım) Ankara: Türk Psikologlar Derneği Yayınlarii, s.5-51.

Tokunaga, S., R., (2011). Social networking site or social surveillance site? Understanding The Use of Interpersonal Electronic Surveillance in Romantic Relationships. Computers in Human Behavior Journal, 27, 705-708.

Topkara, M. (2011). Kadın ve erkek ilişkilerinin psikolojisi. İstanbul: Karma Kitaplar. 
Tortamış, M. (2014). Evli bireylerde romantik kıskançlı türü ve aldatma eğiliminin şema terapi modeli çerçevesinde değerlendirilmesi. Yüksek Lisans Tezi. Hacettepe Üniversitesi, Sosyal Bilimler Enstitüsü, Ankara.

White, G. L. (1981). A model of romantic jealousy. Motivation and Emotion, 5(4), 295-310.

Yaşlioğlu, M. M. (2017). Sosyal bilimlerde faktör analizi ve geçerlilik: Keşfedici ve doğrulayıcı faktör analizlerinin kullanılması. İstanbul Üniversitesi İşletme Fakültesi Dergisi, 46(Özel Sayı), 74-85.

Yavuz, H. (2007). Çalı̧anlarda mobbing (Psikolojik Şiddet) algısını etkileyen faktörler: SDÜ Tip fakültesi üzerine bir araştırma. Yüksek Lisans Tezi. Süleyman Demirel Üniversitesi Sosyal Bilimler Enstitüsü, Isparta.

\section{Kaynakça Bilgisi/Citation Information}

Aydın, Y. E. ve Uzun, N. B. (2021). Romantik İlişkilerde Sosyal Medya Kıskançlı̆̆ı Ölçeği (RİSMKÖ): Geçerlik ve güvenirlik çalışması. OPUS- Uluslararası Toplum Araştırmaları Dergisi, 18(44), 78837911. DOI:10.26466//opus.890331. 